\title{
The Press Can Make a Difference
}

\section{Clarence W Thomas*}

Mass Communications in The Robertson School of Media and Culture, USA

With the recent observation of the Dr. Martin Luther King, Jr. Day (a national holiday) and on the eve of Black History Month 2014, it is important to note that Dr. King, the major Civil rights leader of his era, once termed the racial conflict in America as "a struggle between the forces of good and evil." It is also important to note that said conflict was (at least in part) addressed and challenged by the press in America. During the movement, many black and white Americans spoke out against racial injustice and rallied to erase the evils of racism and segregation. Harry Golden, a journalist and author, was one such person. As a northern Jew transplanted to the South, Golden witnessed the suffering and cruelty inflicted upon blacks by southern whites and empathized with the embattled blacks. Golden, a champion of civil rights, urged the deliverance of black Americans from the evil of racism and the wrong of segregation. His advocacy of civil rights exemplified the zeal with which some segments of the press not only covered but facilitated the civil rights movement. Golden's experience with race relations in Charlotte, North Carolina led him to believe that southern whites "put all their efforts into denying humanity to Negroes, depriving and dehumanizing them because of their color." As a result of his insight into southern race relations, he foresaw a revolution which he believed the major southern daily newspapers, all owned by whites, would downplay because "to report this story meant describing the lot of the Negro." To forestall this eventuality, during the 1950s and 1960s Golden editorialized in his newspaper, the Carolina Israelite. He also wrote books, wrote articles for other newspapers and magazines, and made personal and television appearances. He utilized these outlets to foster better understanding and relations between black and white Americans. With the tools of his outspoken views and satiric humor, Golden wrote about the struggle for black civil rights by vividly illustrating the absurdity of racism and the ludicrous nature of segregationist traditions and policies.

Through Harry Golden (The Serious Humor of Harry Golden by Thomas) we learned that the press can make a difference!
*Corresponding author: Clarence W Thomas, Associate Professor, Mass Communications in The Robertson School of Media and Culture, USA, Tel: 804827-3772; E-mail: cwthomas@vcu.edu

Received January 23, 2014; Accepted January 24, 2011; Published January 25 2014

Citation: Thomas CW (2014) The Press Can Make a Difference. J Mass Communicat Journalism 4: e153. doi:10.4172/2165-7912.1000e153

Copyright: (c) 2014 Thomas CW. This is an open-access article distributed under the terms of the Creative Commons Attribution License, which permits unrestricted use, distribution, and reproduction in any medium, provided the original author and source are credited. 